\title{
Stage-specific Plasmodium falciparum immune responses in afebrile adults and children living in the Greater Accra Region of Ghana
}

\author{
Festus K. Acquah 1,2, Aminata C. Lo ${ }^{1,3}$, Kwadwo Akyea-Mensah'1 , Hamza B. Abagna', Babacar Faye ${ }^{4}$,
} Michael Theisen ${ }^{5,6}$, Ben A. Gyan ${ }^{1}$ and Linda E. Amoah ${ }^{1,2^{*}}$ (])

\begin{abstract}
Background: Asymptomatic carriage of Plasmodium falciparum is widespread in adults and children living in malaria-endemic countries. This study identified the prevalence of malaria parasites and the corresponding levels of naturally acquired anti-parasite antibody levels in afebrile adults living in two communities in the Greater Accra Region of Ghana.

Methods: Two cross-sectional studies conducted in January and February 2016 and repeated in July and August 2016 recruited subjects aged between 6 and 75 years from high parasite prevalence (Obom) and low parasite prevalence (Asutsuare) communities. Whole blood ( $5 \mathrm{ml}$ ) was collected from each volunteer, plasma was aliquoted and frozen until needed. An aliquot $(10 \mu \mathrm{l})$ of the blood was used to prepare thick and thin blood smears, $100 \mu \mathrm{l}$ was preserved in Trizol and the rest was separated into plasma and blood cells and each stored at $-20^{\circ} \mathrm{C}$ until needed. Anti-MSP3 and Pfs 230 antibody levels were measured using ELISA.

Results: Asexual parasite and gametocyte prevalence were higher in Obom than Asutsuare. Antibody (IgG, IgG1, $\lg \mathrm{G} 3, \lg \mathrm{M}$ ) responses against the asexual parasite antigen MSP3 and gametocyte antigen Pfs 230 were higher in Obom during the course of the study except for lgM responses against Pfs230, which was higher in Asutsuare than in Obom during the rainy season. Antibody responses in Asutsuare were more significantly associated with age than the responses measured in Obom.

Conclusion: The pattern of antibody responses measured in people living in the high and low malaria transmission setting was similar. All antibody responses measured against the asexual antigen MSP3 increased, however, IgG and lgG1 responses against gametocyte antigen Pfs230 decreased in moving from the dry to the peak season in both sites. Whilst asexual and gametocyte prevalence was similar between the seasons in the low transmission setting, in the high transmission setting asexual parasite prevalence increased but gametocyte prevalence decreased in the rainy season relative to the dry season.
\end{abstract}

Keywords: Transmission, Gametocyte, Afebrile, Antibody

*Correspondence: Lamoah@noguchi.ug.edu.gh

${ }^{1}$ Immunology Department, Noguchi Memorial Institute for Medical Research (NMIMR), University of Ghana, Accra, Ghana

Full list of author information is available at the end of the article

\section{Background}

Asymptomatic carriage of malaria parasites has been associated with the development of immunity to malaria mainly due to continuous exposure of the host's immune

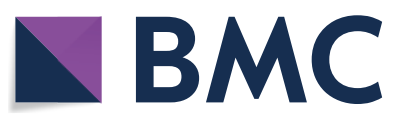

(c) The Author(s) 2020. This article is licensed under a Creative Commons Attribution 4.0 International License, which permits use, sharing, adaptation, distribution and reproduction in any medium or format, as long as you give appropriate credit to the original author(s) and the source, provide a link to the Creative Commons licence, and indicate if changes were made. The images or other third party material in this article are included in the article's Creative Commons licence, unless indicated otherwise in a credit line to the material. If material is not included in the article's Creative Commons licence and your intended use is not permitted by statutory regulation or exceeds the permitted use, you will need to obtain permission directly from the copyright holder. To view a copy of this licence, visit http://creativeco mmons.org/licenses/by/4.0/. The Creative Commons Public Domain Dedication waiver (http://creativecommons.org/publicdomain/ zero/1.0/) applies to the data made available in this article, unless otherwise stated in a credit line to the data. 
(See figure on next page.)

Fig. 1 A map of Ghana projecting study sites located within the Greater Accra Region. The map was created using shapefiles from the Survey Department of the Ghana Statistical Services and ArcMap GIS v10.5 (no administrative permissions were needed to access the shapefiles). Courtesy Mr Richard Adade, GIS and Remote Sensing Unit, Department of Fisheries and Aquatic Sciences, Centre for Coastal Management, University of Cape Coast, Cape Coast, Ghana

system to the Plasmodium parasites [1]. Low parasite density in low transmission settings as well as frequent exposure to similar parasite isolates in high transmission settings have been suggested to enhance the establishment of asymptomatic infections [2]. The level of exposure and rate at which antibodies against both the asexual and sexual stage (gametocytes) parasites are acquired and boosted may be different for people living in different malaria transmission settings [1].

The propagation of Plasmodium parasites within the human erythrocyte, which is critical for the survival of the parasite is initiated by the merozoite. The merozoite is one of several daughter cells released from a mature schizont, which proceed to invade a new host erythrocyte and continue the asexual erythrocytic cycle of the parasite [3]. Merozoites are not contained within erythrocytes and as such their surface antigens are exposed directly to the host's immune system. A number of antigens expressed on the surface of the Plasmodium falciparum merozoite, including the merozoite surface protein 1 (MSP1) and 3 (MSP3) have been validated as malaria vaccine candidates $[4,5]$ due to their ability to induce protective antibodies against malaria. Antibodies specific to MSP3 exert anti-parasite effects, either through inhibition of the merozoite invasion in erythrocytes or in cooperation with mononuclear cells through antibodydependent cellular inhibition and opsonic phagocytosis $[6,7]$. During the erythrocytic cycle, some of the asexual parasites develop into sexual forms: gametocytes. Antigens, including Pfs230 and Pfs48/45, which are expressed during gametocytogenesis have been found to be immunogenic $[8,9]$. Pfs230 is a gamete surface antigen [10-12] and marked as a transmission blocking vaccine candidate [13]. Antibodies against Pfs 230 have been detected in populations naturally exposed to malaria parasites [14, 15]. Such antibodies together with specific antibodies generated in small rodents have been shown to inhibit parasite development in the standard membrane-feeding assay (SMFA) considered the 'gold standard' assay for functional transmission-blocking antibodies [16-18]. These antibodies, however, have been suggested to be very short lived, peaking during the transmission season [19] and are more prevalent in children than in adults [15].

Immunoglobulin G (IgG) antibodies have been shown to be a very important component of humoral immunity in the fight against Plasmodium infections as they have associated with protections against infection [20-22] and transmission-reducing immunity [23, 24]. Cytophilic antibodies (IgG1 and IgG3) have been shown to be particularly important in anti-malarial immunity and associated with protection from the disease [25-29]. Monitoring antibody responses in asymptomatic individuals is thus a valuable tool for monitoring the acquisition of anti-disease immunity as well as the frequency and magnitude of parasite infection [1]. A few earlier studies have characterized natural antibody responses to both asexual and sexual stage antigens, however these studies have only looked into immune responses in asymptomatic children below the age of 12 years [15] or in a symptomatic population [30]. Other studies on afebrile individuals have characterized antibody responses against sporozoite [31], asexual [32, 33] or only sexual stage [34] antibody responses amongst a cohort of Ghanaians. This current study goes further to compare the characteristics of naturally acquired immune responses to asexual parasite antigen MSP3 and sexual stage antigen Pfs230 in both afebrile adults and children living in two communities with different malaria parasite prevalence and transmission intensities.

\section{Methods \\ Ethics statement}

The Institutional Review Board (IRB) of Noguchi Memorial Institute for Medical Research granted ethical approval for the study (Study number 089/14-15). Written informed consent was obtained individually from all participants before they were enrolled into the study.

\section{Study site}

This study was carried out in Obom and Asutsuare (Fig. 1), both in the Greater Accra Region of Ghana [35]. Obom is a semi-rural community in the Ga South Municipality. Malaria transmission in Obom is perennial, although it has a peak transmission period from May to September. According to ongoing mapping studies in the community, malaria parasite prevalence in Obom was estimated at $41 \%$ during the peak transmission period in 2014 [15]. Asutsuare is a semi-rural community located in the Shai-Osudoku district of Dangme West Municipality. Malaria transmission is low but perennial, and peaks slightly during and immediately after the major rainy 


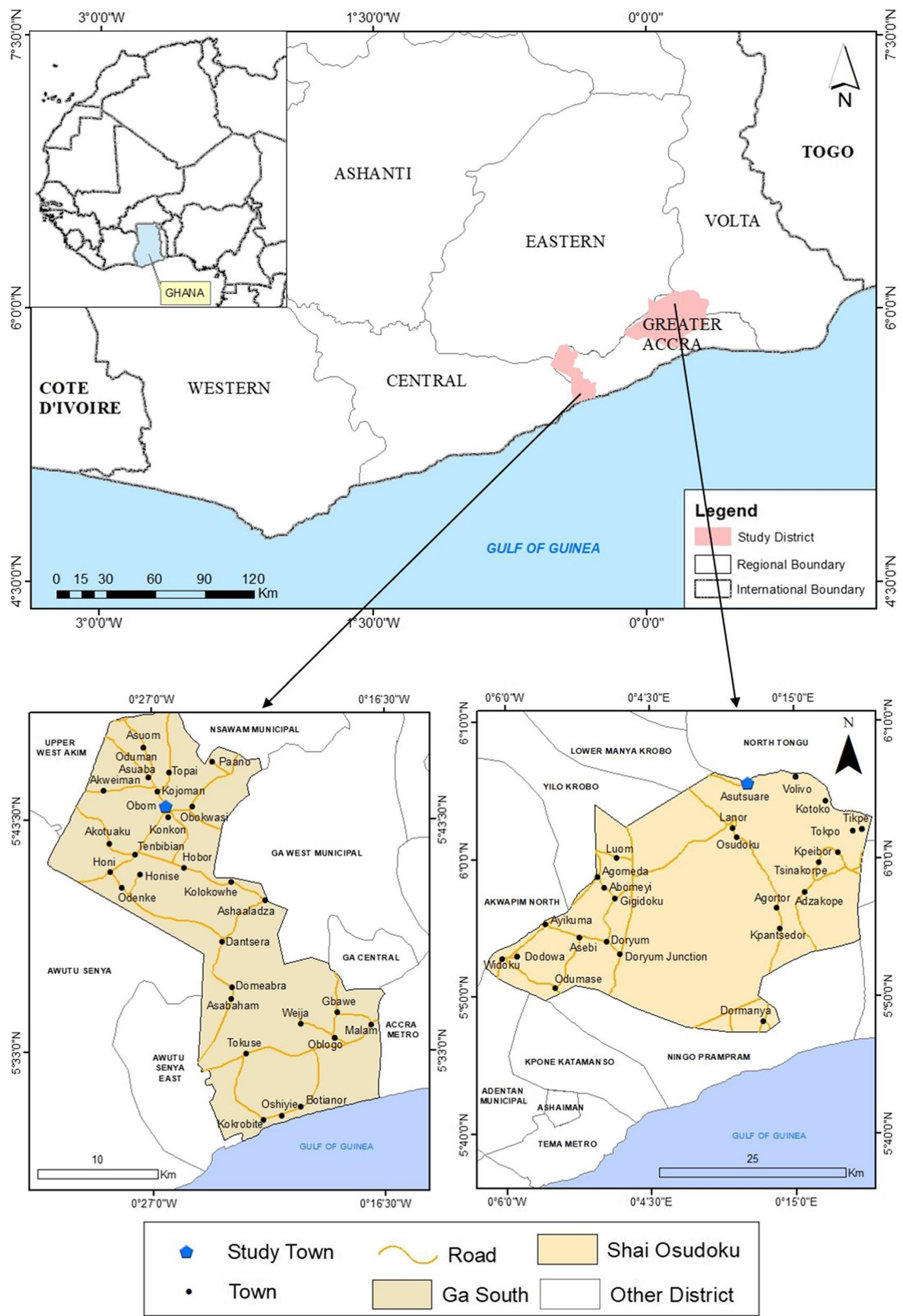


season (April to July) and is lowest during the dry season [36].

\section{Sample collection}

Volunteers aged between 6 and 75 years old and without any symptom of malaria were recruited into a crosssectional study in February 2016 (dry season), which included 264 volunteers from Obom and 230 volunteers from Asutsuare. In July 2016 (rainy season) a second set of volunteers was recruited, 192 from Obom and 174 from Asutsuare, which included 120 volunteers from the off-peak season sample collection for both sites. Venous blood $(5 \mathrm{ml})$ was collected from each volunteer into acid dextrose vacutainer tubes on the day of recruitment. An aliquot $(10 \mu \mathrm{l})$ of the blood was used to prepare thick and thin blood smears, $100 \mu \mathrm{l}$ was preserved in Trizol and the rest was separated into plasma and blood cells via centrifugation and independently stored at $-20^{\circ} \mathrm{C}$ until used.

\section{Parasite detection}

The thin and thick blood smears were processed and used to identify and quantify the presence of $P$. falciparum parasites [37]. Briefly, thin smears were air dried, fixed in 100\% methanol and then stained for $15 \mathrm{~min}$ in a $10 \%$ Giemsa stain solution. Thick smears were air dried and stained in 10\% Giemsa for $15 \mathrm{~min}$. Both set of slides were subsequently observed using $100 \times$ oil immersion microscope. Parasite density was estimated based on the total number of parasites counted per 200 white blood cells (WBCs). Two independent microscopists read the stained slides.

\section{Gametocyte detection}

RNA was isolated from the Trizol-preserved whole blood using the Quick RNA miniprep kit (Zymo Research, USA) according to manufacturer's instructions and subsequently converted into cDNA using the Protoscript II first strand cDNA synthesis kit (NEB, UK) as previously described [38]. Genomic DNA contamination of each extracted RNA was assessed as previously described [39]. A semi-quantitative Pfs 25 mRNA RT-PCR method similar to that described by Ayanful-Torgby et al. [39, 40] was used to determine gametocyte prevalence. Briefly, $300 \mathrm{nM}$ of Pfs $25 \mathrm{~F}$ and R primers were added to $2 \mathrm{ul}$ of cDNA (1:10) and fast SYBR ${ }^{\circledR}$ Green $2 \mathrm{X}$ master mix RTPCR kit (Applied Biosystems). The reactions were run in triplicate on a QuantStudio ${ }^{\text {TM }}$ Real-Time PCR System (Thermo Scientific, USA). The primer validation and all positive and negative controls used in this experiment have been previously described $[39,40]$.

\section{Enzyme-linked immunosorbent assay (ELISA)}

Antibody responses including IgG, IgM, IgG1, and IgG3 against recombinant $P$. falciparum sexual stage and asexual stage antigens were quantified using an indirect ELISA protocol [41]. The antigens used in this study include Pfs230 [14] and MSP3 [30] produced in Lactococcus lactis. Briefly Pfs 230 antigen was diluted to $1 \mu \mathrm{g} /$ $\mathrm{ml}$ in carbonate buffer $[14,15]$ and MSP3 diluted to $1 \mu \mathrm{g} /$ $\mathrm{ml}$ in phosphate-buffered saline (1X PBS, pH7.2) $[15,30]$ and $100 \mu \mathrm{l} /$ well of the diluted antigen was used to coat the wells of Maxisorp NUNC plates (Nunc Maxisorp, UK) overnight at $4{ }^{\circ} \mathrm{C}$. The plates were subsequently washed with wash buffer (PBST; 1X PBS supplemented with $0.05 \%$ Tween 20 at pH7.2), blocked with $3 \%$ nonfat skimmed milk (Marvel, UK) in1X PBS and incubated at room temperature (RT) for $1 \mathrm{~h}$. The plates were then incubated with $100 \mu \mathrm{l} /$ well of plasma diluted to 1:200 for IgG and IgM and 1:100 for IgG1 and IgG3 in 1\% of non-fat skimmed milk in 1X PBS. Two pools of sera, one previously determined to have high concentrations of antibodies against MSP3 and the other against Pfs48/45, were used separately as a standard calibrator. The standards were used at a starting dilution of 1:400 for IgG and IgM and 1:100 for the cytophilic sub-classes IgG1 and IgG3 and serially diluted two-fold for an additional seven concentrations. Plasma samples were incubated for $1 \mathrm{~h}$ at RT for IgG and IgM and $37^{\circ} \mathrm{C}$ for IgG1 and IgG3. Each plate was washed three times with wash buffer after every incubation step. The plates were subsequently incubated with $100 \mu \mathrm{l} /$ well of goat anti-human IgG or IgM at a 1:3000 dilution or $100 \mu \mathrm{l} /$ well of goat anti-human IgG1 or IgG3 at a dilution of 1:1000 for $1 \mathrm{~h}$ at RT, followed by a final wash step. The plates were then incubated with $50 \mu \mathrm{l} /$ well of TMB plus2 for $15 \mathrm{~min}$. Colour development was stopped by the addition of $50 \mu \mathrm{l} /$ well of $0.2 \mathrm{M} \mathrm{H}_{2} \mathrm{SO}_{4}$ and optical densities (OD) read at $450 \mathrm{~nm}$ using a 96-well ELISA plate reader (Biotek, VT, USA).

\section{Statistical and data analysis}

The cut-off for positivity for gametocyte presence by RT-PCR as determined by the no template control was 'undetermined'. Any sample that yielded a CT value other than 'undetermined' was scored as positive.

For each measured antibody, OD data were normalized against the standard calibrator. OD data were converted into concentration in arbitrary units using the 4-parameter logistic curve-fitting program, ADAMSEL (version b040; Ed Remarque ${ }^{\mathrm{TM}}$ ). Log10-transformed OD data from naïve malaria volunteers from the two seasons were used to define a common cut-off from which seroprevalence was calculated as the population of sample with Log10-transformed ODs higher than the common 
Table 1 Demographic characteristics and parasitological indices of study participants

\begin{tabular}{|c|c|c|c|c|}
\hline & \multicolumn{2}{|l|}{ Obom } & \multicolumn{2}{|l|}{ Asutsuare } \\
\hline & Dry (264) & Rainy (192) & Dry (230) & Rainy (174) \\
\hline \multicolumn{5}{|l|}{ Age/years } \\
\hline$\leq 10$ years $(\mathrm{N}(\%))$ & $36(13.6)$ & $35(18.2)$ & $22(9.6)$ & $18(7.8)$ \\
\hline $11-15$ years $(\mathrm{N}(\%))$ & $117(44.3)$ & $78(40.6)$ & $58(25.2)$ & $42(24.1)$ \\
\hline$\geq 16$ years $(\mathrm{N}(\%))$ & $101(38.3)$ & $73(38.0)$ & $141(61.3)$ & $113(64.9)$ \\
\hline Asexual carriers & $32(12.1)$ & $62(32.3)$ & $8(3.5)$ & $7(4.0)$ \\
\hline \multicolumn{5}{|l|}{ 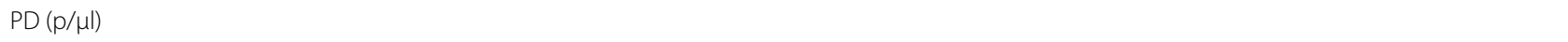 } \\
\hline Min-Max & $16-5080$ & $16-4219$ & $40-280$ & $16-1553$ \\
\hline Median (IQR) & $120(80-350)$ & $112(48-528)$ & $40(40-170)$ & $400(32-955)$ \\
\hline Gametocyte carriers & $47(17.8)$ & $30(15.6)$ & $3(1.3)$ & $3(1.7)$ \\
\hline
\end{tabular}

$N$ number in counts, $p / \mu /$ parasites per $\mu$ l of blood, Min minimum, Max maximum, $I Q R$ interquartile range, $P D$ parasite density

The sites are listed with the number of study participants in brackets. The values in the table represent frequency as counts ( $N$ ) and $\%$ in brackets of the total population at each site during each time point. Study participants were stratified into three age groups, $\leq 10$ years, $11-15$ years and $\geq 16$ years. $N$ number of people. Asexual parasite prevalence was detected by light microscopy and gametocyte prevalence by Pfs 25 mRNA RT-PCR

cut-off. Analysis of data and graphics was performed using Kruskal-Wallis test, Spearman correlation and other statistical tests (Graph Pad Prism version 7). Statistical significance was set as $\mathrm{P} \leq 0.05$, unless otherwise stated.

\section{Results}

\section{Study participants}

The study recruited 230 and 174 volunteers from Asutsuare during the dry (January-February) and rainy (July-August) seasons, respectively, and 264 and 192 volunteers from Obom during the dry (January-February) and rainy (July-August) seasons, respectively. Volunteers aged 10 years and below were the least represented in both sites at both sampling time points, and participants aged above 15 years were the most represented in Asutsuare at both sampling time points (Table 1). Age data were not captured for some of the samples, making the sum of samples analysed in the three cohorts (age-stratified data) less than the total number of samples recruited. Gametocyte prevalence by microscopy was very low in both communities, with the prevalence ranging between 0.4 and $0.6 \%$. Asexual stage parasite prevalence and density was much higher in Obom than in Asutsuare during both the dry and rainy seasons (Table 1). Whilst there was an increase in the prevalence of asymptomatic parasite carriers from the dry to the rainy season in Obom, asymptomatic parasite prevalence in Asutsuare remained relatively the same at the two time points (Table 1 ).

\section{Asexual antibody responses}

At the community level, total IgG for naturally induced antibodies against MSP3 increased significantly in the rainy season compared to the dry season for both sites
(Fig. 2a), with the increase in Asutsuare being greater than in Obom (Kruskal-Wallis test, $\mathrm{p}<0.001$ in Asutsuare and $\mathrm{p}<0.01$ in Obom). Total IgG levels in Obom were significantly higher than in Asutsuare at all time points (Kruskal-Wallis test, $\mathrm{p}<0.05$, Additional file 1: Table S1). A similar trend was observed for naturally induced IgM, IgG1 and IgG3 antibodies against MSP3 (Figs. 2b and 3a, b), where all responses measured in Obom were significantly higher than those recorded in Asutsuare (Additional file 1) and the rainy season having higher levels compared to the dry season (Figs. 2a, b and 3a, b).

During the dry season, age was found to correlate with IgG1 as well as IgG3 responses against MSP3 in both Obom and Asutsuare. In Obom, the correlation was significant but weak; Spearman $\mathrm{r}=0.1514, \mathrm{p}=0.0228$ (IgG1) and Spearman $\mathrm{r}=0.2633, \mathrm{p}=0.0001$ (IgG3), whilst in Asutsuare, the correlations although higher than Obom were still weak; Spearman $r=0.3341$ (IgG1), Spearman $r=0.4057$ (IgG3), $\mathrm{p}<0.0001$ for both) (Additional file 1).

Significant differences in IgG1 as well as IgG3 responses against MSP3 amongst the three age groups at each site were noted (Fig. 3a, b). IgG1 responses against MSP3 in Obom were significantly lower (Dunn's Multiple Comparison Test, $\mathrm{p}<0.05)$ in young children $(\leq 10$ years) than in the older children (11-15 years). The measured IgG3 responses against MSP3 in the young children ( $\leq 10$ years) were significantly lower (Dunn's Multiple Comparison Test, $\mathrm{p}<0.01)$ than responses measured in the adults ( $\geq 16$ years) (Fig. $3 \mathrm{~b}$ ).

In Asutsuare, IgG1 responses against MSP3 (Fig. 3a) were significantly higher in the adults ( $\geq 16$ years) compared to both young children ( $\leq 10$ years) and the older children (11-15 years) (Dunn's Multiple Comparison Test, $\mathrm{p}<0.01$ and 0.001 , respectively). A similar 

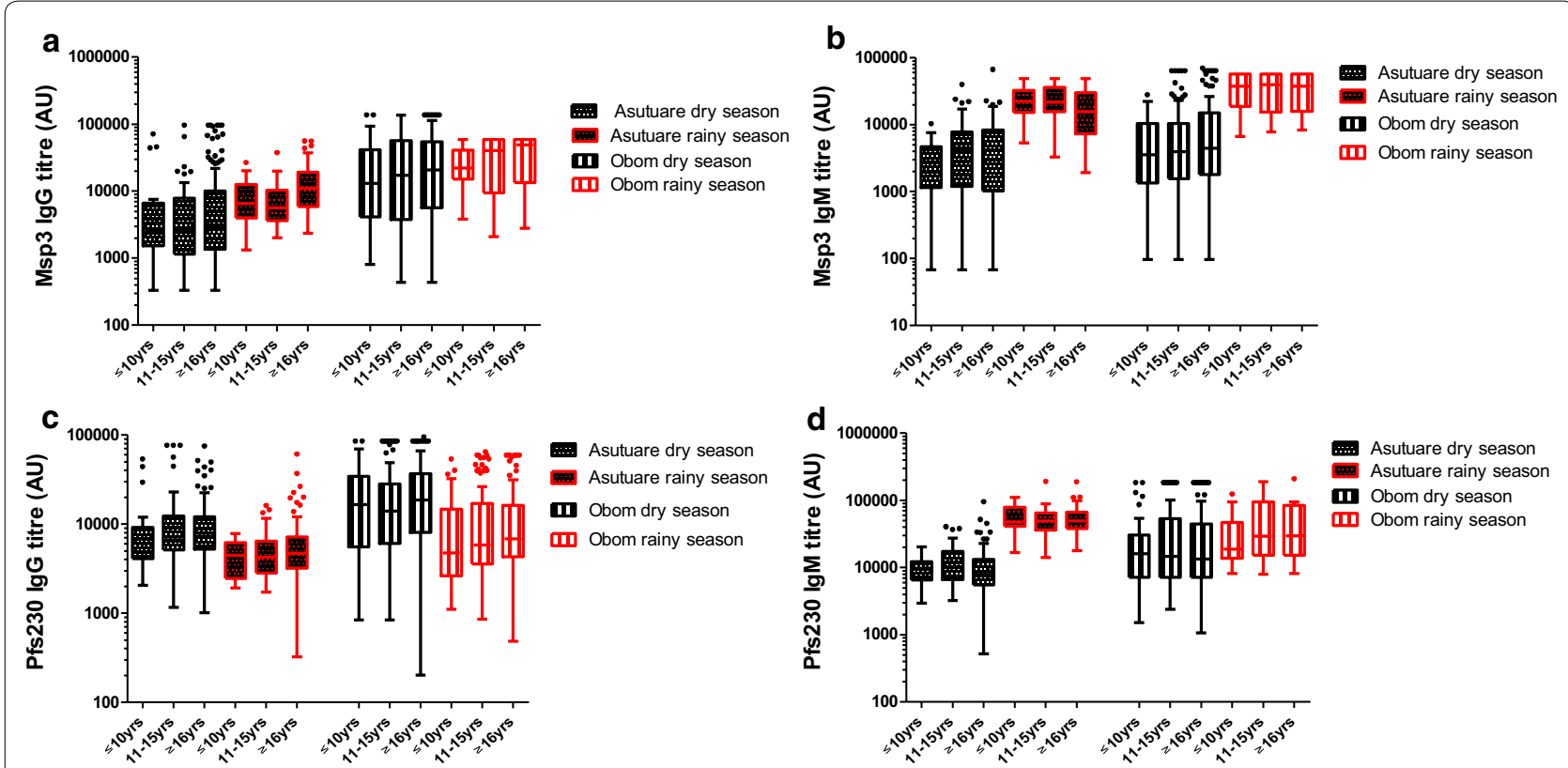

Fig. 2 Age-stratified IgG and IgM responses. Antibody responses: IgG responses against MSP3 (a) and Pfs230 (c) and IgM responses against MSP3 (b) and Pfs230 (d) in the study participants were stratified into children 10 years old and below ( $\leq 10$ years), children between 11 and 15 years (11-15 years) and adults 16 years and above ( $\geq 16$ years). Measurements were made in both the dry and rainy season from Obom and Asutsuare. Antibody concentrations are presented in arbitrary units (AU) on a Tukey box-and-whiskers plot
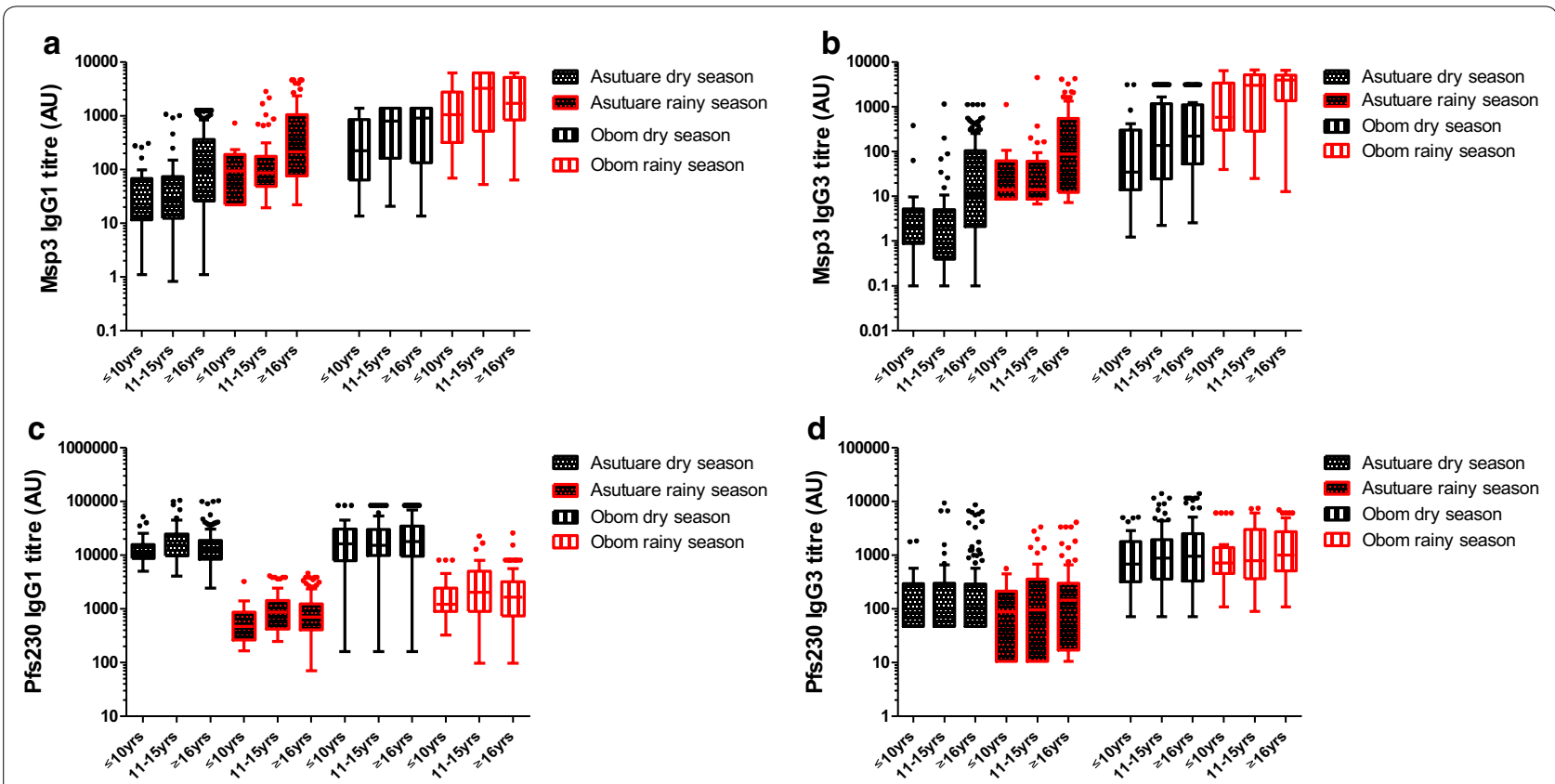

Fig. 3 Age-stratified lgG1 and IgG3 responses. IgG1 responses against MSP3 (a) and Pfs230 (c) and lgG3 responses against MSP3 (b) and Pfs230 (d) in the study participants were stratified into children 10 years old and below ( $\leq 10$ years), children between 11 and 15 years (11-15 years) and adults 16 years and above ( $\geq 16$ years). Measurements were made in both the dry and rainy season from Obom and Asutsuare. Antibody concentrations are presented in arbitrary units (AU) on a Tukey box-and-whiskers plot 
observation was made for anti-MSP3 IgG3 responses where the adults had significantly higher responses than both young children and older children (Dunn's Multiple Comparison Test, $\mathrm{p}<0.05$ and 0.001 , respectively).

During the rainy season, total IgG (Spearman $\mathrm{r}=0.2027, \mathrm{p}=0.0207$ ) (Fig. 2a) and IgG3 (Spearman $\mathrm{r}=0.2449, \mathrm{p}=0.0059)$ against MSP3 in volunteers from Obom showed a positive but weak correlation with age. In Asutsuare, total IgG (Spearman $r=0.3672, p<0.0001$ ), IgG1 (Spearman $\mathrm{r}=0.3962$, $\mathrm{p}<0.0001$ ) and IgG3 (Spearman $\mathrm{r}=0.4485, \mathrm{p}<0.0001)$ responses against MSP3 (Fig. 3a, b) significantly correlated weakly but positively with age. Anti-MSP3 IgM antibodies correlated inversely with age in Asutsuare (Spearman $\mathrm{r}=-0.1788, \mathrm{p}<0.05$ ) but not in Obom (Fig. 2b).

Anti-IgG3 responses measured in Obom against MSP3 remained significantly lower in the young children ( $\leq 10$ years) compared to the adults ( $\geq 16$ years) (Dunn's Multiple Comparison Test, $\mathrm{p}<0.05$ ), however, IgG, IgG3 and IgM levels across the three age groups were similar during the rainy season (Figs. 2a, b and 3a, b). In Asutsuare, anti-IgG1 and IgG3 responses measured against MSP3 was significantly higher in adults than those measured in the young and older children (Dunn's Multiple Comparison Test, $\mathrm{p}<0.05$ (young children) and $\mathrm{p}<0.001$ (older children) for both). Total IgG responses were significantly higher in adults (Dunn's Multiple Comparison Test, $\mathrm{p}<0.001)$ than in older children, whilst no differences in IgM responses were measured between the three groups (Dunn's Multiple Comparison Test, $\mathrm{p}>0.05$ for all combinations).

Contribution of the measured cytophilic antibodies to variations in measured total IgG was assessed by fitting a linear regression model using IgG1 and IgG3 as explanatory variables for total IgG concentrations against MSP3. The results showed that in the dry season, the independent variables (anti-IgG1 and IgG3) could not explain the variations observed in total IgG responses in Obom and could only account for $3.3 \%$ of the variations in total IgG observed in Asutsuare (Table 2). In the rainy season however, about 70\% (for Asutsuare) and 71\% (for Obom) of the variations in total anti-MSP3 IgG could be explained by variations in the measured $\operatorname{IgG} 1$ and $\operatorname{IgG} 3\left(R^{2}=0.699\right.$, $\mathrm{p}<0.001$ and $\mathrm{R}^{2}=0.709, \mathrm{p}<0.001$ for Asutsuare and Obom, respectively). All variance inflation factors (VIFs) for all the analyses were less than 1.8 (Additional file 2).

\section{Sexual stage (Pfs230) antibody responses}

Within the community, all antibody responses measured against Pfs230 in Obom were significantly (KruskalWallis test, $\mathrm{p}<0.001$ ) higher than that measured in Asutsuare. Moving from the dry to the rainy seasons, naturally induced IgG responses against Pfs230 decreased
Table 2 Multivariate linear regression relating total IgG with IgG1 and IgG3

\begin{tabular}{|c|c|c|}
\hline \multirow[t]{2}{*}{ Independent variables } & \multicolumn{2}{|c|}{$\lg G 1$ and $\lg G 3$} \\
\hline & $\overline{R^{2}}$ & $\mathbf{P}$ \\
\hline \multicolumn{3}{|l|}{ MSP3 } \\
\hline Asutsuare (dry) & 0.033 & 0.018 \\
\hline Asutsuare (rainy) & 0.699 & $<0.001$ \\
\hline Obom (dry) & -0.006 & 0.426 \\
\hline Obom (rainy) & 0.709 & $<0.001$ \\
\hline \multicolumn{3}{|l|}{ Pfs 230} \\
\hline Asutsuary (dry) & 0.455 & $<0.001$ \\
\hline Asutsuary (rainy) & 0.111 & $<0.001$ \\
\hline Obom (dry) & 0.313 & $<0.001$ \\
\hline Obom (rainy) & 0.003 & 0.301 \\
\hline
\end{tabular}

$R^{2}$ coefficient of determination; $P \mathrm{p}$ value

significantly (Kruskal-Wallis test $\mathrm{p}<0.001$ ) (Fig. 2c), whilst anti-IgM increased significantly (Kruskal-Wallis test, $\mathrm{p}<0.001)$ in both sites. Anti-IgM levels in Obom were significantly (Kruskal-Wallis test, $\mathrm{p}<0.001$ ) (Fig. 2d) higher than those measured in Asutsuare in the dry season but in the rainy season, IgM responses measured in Obom were significantly (Kruskal-Wallis test, $\mathrm{p}<0.001)$ lower than those measured in Asutsuare (Fig. 2d). Anti-IgG1 responses measured in both sites were similar to that of total IgG, with a decrease observed in moving from the dry to the rainy season. Anti-IgG1 levels measured in Obom in the rainy season were significantly (Kruskal-Wallis test, $\mathrm{p}<0.001$ ) higher than measured in Asutsuare in the same season but antiIgG1 responses measured in the dry season were similar at both sites (Fig. 3c). Anti-IgG3 responses against Pfs 230 were similar between seasons in both sites (Fig. 3d).

During the dry season, age was not found to correlate with any of the Pfs 230 antibody responses measured in Obom, however a significant (Spearman $r=-0.020$, $\mathrm{p}=0.0029$ ) very weak negative correlation was observed between age and IgM responses in Asutsuare.

During the rainy season, age positively (Spearman $\mathrm{r}=0.1718, \mathrm{p}=0.0172)$ correlated with anti-Pfs230 total IgG in volunteers from Obom, whilst age correlated significantly (Spearman $r=0.2582, p=0.0007$ ) with IgG3 responses in Asutsuare. Anti-IgG1 responses against Pfs230 from both sites correlated negatively with age but the correlation was not significant (Spearman $r=-0.169$, $\mathrm{p}=0.8233$ for Obom and Spearman $\mathrm{r}=-0.0571$, $\mathrm{p}=0.5011$ for Asutsuare).

The weak correlation of antibody responses with age was reinforced when no significant differences were observed between all the various antibody responses measured against Pfs 230 in the young children, the older 
children and the adults from both Obom and Asutsuare during both the dry and rainy season (Figs. 2c, d and 3c, d). Similar to the asexual stage antibodies against MSP3, variations in measured anti-IgG1 and IgG3 against Pfs 230 could not account for the variations in IgG measure in Obom but could account for $11 \%$ of the IgG variations measured in Asutsuare (Table 2). However, during the dry season, the $R^{2}$ increased to $0.455(\mathrm{p}<0.001$ for Asutsuare) and $0.313(\mathrm{p}<0.001$ for Obom) (Table 2). All VIFs were approximately 1 .

The parasite density of samples collected from Obom during both the dry and rainy season did not correlate with any of the measured antibody (asexual stage or the gametocyte) responses. There were too few samples with microscopic densities of parasites in Asutsuare to do any statistical analysis (Additional file 3).

\section{Discussion}

Asymptomatic carriage of $P$. falciparum parasites exposes the host to both asexual disease-causing parasites as well as the sexual transmissible forms of the parasite. This primes as well as boosts the host's immune system to produce antibodies against both asexual and sexual (gametocyte) forms of the parasite. Inhabitants of malaria-endemic countries, especially children, are highly at risk of being infected with the malaria parasite and have previously been the focus of earlier studies to understand and identify differences in asymptomatic parasite carriage in high and low malaria transmission communities in Ghana $[15,40]$. In this study, afebrile adults and children were recruited from communities of varying malaria transmission intensities and parasite prevalence to enable the comparison of naturally acquired immune responses against asexual and sexual stage antigens in both the dry and subsequent rainy season.

As anticipated, the prevalence of asymptomatic carriers was significantly higher in Obom, the high parasite prevalence setting, than in Asutsuare where P. falciparum parasite prevalence has been reported to be very low for over a decade $[34,36]$. No significant difference was observed in asexual parasite carriage between the dry and rainy season in Asutsuare, mainly because malaria is low and perennial [36] and supports an earlier report on asexual parasite prevalence in another low malaria parasite intensity setting of Ghana [40]. However, there was an almost two-fold increase in microscopic levels of asexual parasite carriage in moving from the dry to the rainy season in Obom, where malaria is high and seasonal. Gametocyte carriage in Obom significantly reduced in moving from the dry to the rainy season. A similar finding of reduced gametocyte carriage in the peak relative to the off-peak season has been reported in young children from Obom [40]. The absence of variation in gametocyte carriage across the dry and rainy season in Asutsuare is supportive of the very low year-round malaria transmission recorded in Asutsuare. The low gametocyte prevalence identified in the participants from Asutsuare supports a recent report that identified low gametocyte prevalence amongst children and adults, including pregnant women in Asutsuare [34].

A significant increase in the community-wide levels of anti-MSP3 IgM was anticipated and confirmed in moving from the dry to the rainy season in Obom, where there was a subsequent increase in asexual parasite prevalence. Interestingly, a similar significant increase in anti-MSP3 IgM was observed in Asutsuare, although asymptomatic carriage of microscopic densities of $P$. falciparum parasites remained the same in moving from the dry to rainy season. One possible explanation for the increase in IgM in rainy season could be an increase in the prevalence of sub-microscopic density infections in the rainy season that was not captured by microscopy but has been reported using more sensitive tools [42]. In Asutsuare, anti-MSP3 IgG did not correlate with age, however the levels in adults during the rainy season were higher than in the children. It is not clear why no age correlation was observed, however, IgG antibody levels have not always been found to correlate with age [43].

Cytophilic (IgG1 and IgG3) responses against MSP3 in Asutsuare were similar in both the dry and rainy season, where the adults had significantly higher levels than both groups of children. This result suggests that more frequent exposure is likely to be required to mature cytophilic antibody responses [7], buttressing the results observed in Obom, where the cytophilic IgG responses were lower in the young children compared with the older children and adults. Multivariate linear regression of the total IgG concentration using the IgG1 and IgG3 concentrations revealed that in the rainy season, IgG1 and IgG3 concentrations accounted for most of the measured total IgG. The differences observed in the rainy season relative to the dry season could be due to the increase in the prevalence of asexual parasites during the rainy season relative to the dry season since IgG1 and IgG3 are known to be potent activators of complement and phagocytic cells [44].

The reduction in the levels of Pfs230 IgG in moving from the dry to the rainy season observed in both Obom and Asutsuare could be due to a reduction in the number of gametocyte carrier, especially in Obom were fewer participants with active gametocyte infections were identified in the rainy relative to the dry season. The higher levels of Pfs230 IgM observed in Asutsuare relative to Obom in the rainy season could be due to very recent gametocyte infections in some participants in Asutsuare as antibody responses to gametocyte antigens have been 
suggested to develop rapidly after exposure [45]. Similarly, the high IgM levels in the rainy season could have helped with antibody clearance of the mature gametocytes from circulation, thereby causing a reduction in the detected levels gametocyte in the rainy season.

The decrease in anti-Pfs230 IgG and IgG1 with increased exposure was not unexpected as antibody responses to gametocyte antigens have been suggested to be influenced more by recent exposure compared with cumulative exposure [17]. Although IgG1 antibodies are known to have a longer half-life than IgG3 [46], the relatively unchanged levels of IgG3 but significantly decreased levels of IgG1 suggests that IgG1 might be the preferred IgG subclass required to clear mature gametocytes from circulation although further studies must be done to ascertain this.

\section{Conclusion}

The pattern of antibody responses measured in people living in the high and low malaria transmission setting was similar. All antibody responses measured against the asexual antigen, MSP3 increased, however, IgG and IgG1 responses against gametocyte antigen Pfs230 decreased in moving from the dry to the peak season in both sites likely due to requirement of IgG1 to clear gametocytes from circulation. Whilst asexual and gametocyte prevalence was similar between the seasons in the low transmission setting, in the high transmission setting asexual parasite prevalence increased but gametocyte prevalence decreased in the rainy season relative to the dry season.

\section{Supplementary information}

Supplementary information accompanies this paper at https://doi. org/10.1186/s12936-020-3146-7.

Additional file 1. Statistical analysis of antibody responses obtained at each site during both the dry and rainy season.

Additional file 2. Regression analysis of antibody responses obtained at each site during both the dry and rainy season.

Additional file 3. Correlation analysis of antibody responses obtained at Obom with age and parasite density.

\section{Abbreviations}

MSP3: Merozoite surface protein 3; Pfs230: Gametocyte antigen; IgG: Immunoglobulin G; IgM: Immunoglobulin M; IgG1: Immunoglobulin G subclass 1; IgG3: Immunoglobulin G subclass 3.

\section{Acknowledgements}

The authors are grateful to all volunteers who participated in this study as well as their guardians for granting consent; to Dr. Kwadwo A Kusi (NMIMR) for help with the statistical analysis and Dr Yaw Aniweh (WACCBIP) for his critical review of the document.

\section{Authors' contributions}

LEA, BG, MT and ACL conceived the study. AL and KAM collected the samples. $\mathrm{AL}$ and KAM performed the experiments. LEA, $\mathrm{HZ}$ and FKA performed the statistical analysis. LEA, FKA, MT and BG contributed in writing the manuscript. All authors read and approved the final manuscript.

\section{Funding}

This project was partly supported by Bill and Melinda gates foundation under the Postdoctoral and Postgraduate Training in Infectious disease research at Noguchi Memorial Institute for Medical Research awarded to AL. LEA and FKA are supported by a World Bank African Centres of Excellence grant (ACE02-WACCBIP).

\section{Availability of data and materials}

All data generated or analysed during this study are included in this published article [and its Additional files]

\section{Ethics approval and consent to participate}

The Institutional Review Board (IRB) of the Noguchi Memorial Institute for Medical Research (NMIMR) gave approval for the original study (\#089/1415) as well as for the reuse of the samples. Participants were enrolled only after written informed consent was obtained. Written parental consent was obtained from the parents or guardians of participants who were minors.

\section{Consent for publication}

Not applicable.

\section{Competing interests}

The authors declare that they have no competing interests.

\section{Author details}

${ }^{1}$ Immunology Department, Noguchi Memorial Institute for Medical Research (NMIMR), University of Ghana, Accra, Ghana. ${ }^{2}$ West African Centre for Cell Biology of Infectious Pathogens (WACCBIP), University of Ghana, Accra, Ghana.

${ }^{3}$ Present Address: Parasitology Department, University Cheikh Anta Diop, Dakar, Senegal. ${ }^{4}$ Parasitology Department, University Cheikh Anta Diop,

Dakar, Senegal. ${ }^{5}$ Department for Congenital Disorders, Statens Serum Institut, Copenhagen, Denmark. ${ }^{6}$ Centre for Medical Parasitology at Department of International Health, Immunology and Microbiology, University of Copenhagen, Copenhagen, Denmark.

Received: 21 November 2019 Accepted: 30 January 2020

Published online: 10 February 2020

\section{References}

1. Doolan DL, Dobano C, Baird JK. Acquired immunity to malaria. Clin Microbiol Rev. 2009:22:13-36.

2. Coleman RE, Kumpitak C, Ponlawat A, Maneechai N, Phunkitchar V, Rachapaew N, et al. Infectivity of asymptomatic Plasmodium-infected human populations to Anopheles dirus mosquitoes in western Thailand. J Med Entomol. 2004:41:201-8.

3. Cowman AF, Crabb BS. Invasion of red blood cells by malaria parasites. Cell. 2006;124:755-66.

4. Nebie I, Diarra A, Ouedraogo A, Soulama I, Bougouma EC, Tiono AB, et al. Humoral responses to Plasmodium falciparum blood-stage antigens and association with incidence of clinical malaria in children living in an area of seasonal malaria transmission in Burkina Faso, West Africa. Infect Immun. 2008:76:759-66.

5. Zerpa NC, Wide A, Noda J, Bermudez H, Pabon R, Noya OO. Immunogenicity of synthetic peptides derived from Plasmodium falciparum proteins. Exp Parasitol. 2006;113:227-34.

6. Muellenbeck MF, Ueberheide B, Amulic B, Epp A, Fenyo D, Busse CE, et al. Atypical and classical memory B cells produce Plasmodium falciparum neutralizing antibodies. J Exp Med. 2013;210:389-99.

7. Singh S, Soe S, Mejia JP, Roussilhon C, Theisen M, Corradin G, et al. Identification of a conserved region of Plasmodium falciparum MSP3 targeted by biologically active antibodies to improve vaccine design. J Infect Dis. 2004;190:1010-8.

8. Williamson KC, Keister DB, Muratova O, Kaslow DC. Recombinant Pfs230, a Plasmodium falciparum gametocyte protein, induces antisera that reduce the infectivity of Plasmodium falciparum to mosquitoes. Mol Biochem Parasitol. 1995;75:33-42. 
9. Healer J, McGuinness D, Hopcroft P, Haley S, Carter R, Riley E. Complement-mediated lysis of Plasmodium falciparum gametes by malariaimmune human sera is associated with antibodies to the gamete surface antigen Pfs230. Infect Immun. 1997;65:3017-23.

10. Kaslow DC. Immunogenicity of Plasmodium falciparum sexual stage antigens: implications for the design of a transmission blocking vaccine. Immunol Lett. 1990;25:83-6.

11. Quakyi IA, Carter R, Rener J, Kumar N, Good MF, Miller LH. The 230-kDa gamete surface protein of Plasmodium falciparum is also a target for transmission-blocking antibodies. J Immunol. 1987;139:4213-7.

12. Vermeulen AN, van Deursen J, Brakenhoff RH, Lensen TH, Ponnudurai T, Meuwissen JH. Characterization of Plasmodium falciparum sexual stage antigens and their biosynthesis in synchronised gametocyte cultures. Mol Biochem Parasitol. 1986;20:155-63.

13. Ong CS, Zhang KY, Eida SJ, Graves PM, Dow C, Looker M, et al. The primary antibody response of malaria patients to Plasmodium falciparum sexual stage antigens which are potential transmission blocking vaccine candidates. Parasite Immunol. 1990;12:447-56.

14. Acquah FK, Obboh EK, Asare K, Boampong JN, Nuvor SV, Singh SK, et al. Antibody responses to two new Lactococcus lactis-produced recombinant Pfs $48 / 45$ and Pfs 230 proteins increase with age in malaria patients living in the Central Region of Ghana. Malar J. 2017;16:306.

15. Amoah LE, Acquah FK, Ayanful-Torgby R, Oppong A, Abankwa J, Obboh EK, et al. Dynamics of anti-MSP3 and Pfs 230 antibody responses and multiplicity of infection in asymptomatic children from southern Ghana. Parasit Vectors. 2018;11:13.

16. Jones S, Grignard L, Nebie I, Chilongola J, Dodoo D, Sauerwein R, et al. Naturally acquired antibody responses to recombinant Pfs 230 and Pfs 48/45 transmission blocking vaccine candidates. J Infect. 2015;71:117-27.

17. Bousema JT, Drakeley CJ, Sauerwein RW. Sexual-stage antibody responses to $P$. falciparum in endemic populations. Curr Mol Med. 2006:6:223-9.

18. Graves PM, Carter R, Burkot TR, Quakyi IA, Kumar N. Antibodies to Plasmodium falciparum gamete surface antigens in Papua New Guinea sera. Parasite Immunol. 1988;10:209-18.

19. Ouedraogo AL, Roeffen W, Luty AJ, de Vlas SJ, Nebie I, Ilboudo-Sanogo $\mathrm{E}$, et al. Naturally acquired immune responses to Plasmodium falciparum sexual stage antigens Pfs $48 / 45$ and Pfs 230 in an area of seasonal transmission. Infect Immun. 2011;79:4957-64.

20. Courtin D, Oesterholt M, Huismans H, Kusi K, Milet J, Badaut C, et al. The quantity and quality of African children's lgG responses to merozoite surface antigens reflect protection against Plasmodium falciparum malaria. PLOS ONE. 2009:4:e7590.

21. Staalsoe T, Shulman CE, Bulmer JN, Kawuondo K, Marsh K, Hviid L. Variant surface antigen-specific lgG and protection against clinical consequences of pregnancy-associated Plasmodium falciparum malaria. Lancet. 2004;363:283-9.

22. Okech B, Mujuzi G, Ogwal A, Shirai H, Horii T, Egwang TG. High titers of IgG antibodies against Plasmodium falciparum serine repeat antigen 5 (SERA5) are associated with protection against severe malaria in Ugandan children. Am J Trop Med Hyg. 2006;74:191-7.

23. Healer J, McGuinness D, Carter R, Riley E. Transmission-blocking immunity to Plasmodium falciparum in malaria-immune individuals is associated with antibodies to the gamete surface protein Pfs 230 . Parasitology. 1999;119:425-33.

24. Theisen M, Roeffen W, Singh SK, Andersen G, Amoah L, van de VegteBolmer $\mathrm{M}$, et al. A multi-stage malaria vaccine candidate targeting both transmission and asexual parasite life-cycle stages. Vaccine. 2014:32:2623-30.

25. Cherif MK, Ouedraogo O, Sanou GS, Diarra A, Ouedraogo A, Tiono A, et al. Antibody responses to $P$. falciparum blood stage antigens and incidence of clinical malaria in children living in endemic area in Burkina Faso. BMC Res Notes. 2017:10:472.

26. Dobano C, Santano R, Vidal M, Jimenez A, Jairoce C, Ubillos I, et al. Differential Patterns of IgG subclass responses to Plasmodium falciparum antigens in relation to malaria protection and RTS,S vaccination. Front Immunol. 2019:10:439.

27. Kana IH, Garcia-Senosiain A, Singh SK, Tiendrebeogo RW, Chourasia BK, Malhotra P, et al. Cytophilic antibodies against key Plasmodium falciparum blood stage antigens contribute to protection against clinical malaria in a high transmission region of Eastern India. J Infect Dis. 2018;218:956-65.

28. Ubillos I, Ayestaran A, Nhabomba AJ, Dosoo D, Vidal M, Jimenez A, et al. Baseline exposure, antibody subclass, and hepatitis B response differentially affect malaria protective immunity following RTS, S/AS01E vaccination in African children. BMC Med. 2018;16:197.

29. Weaver R, Reiling L, Feng G, Drew DR, Mueller I, Siba PM, et al. The association between naturally acquired lgG subclass specific antibodies to the PfRH5 invasion complex and protection from Plasmodium falciparum malaria. Sci Rep. 2016;6:33094.

30. Amoah LE, Nuvor SV, Obboh EK, Acquah FK, Asare K, Singh SK, et al. Natural antibody responses to Plasmodium falciparum MSP3 and GLURP(RO) antigens are associated with low parasite densities in malaria patients living in the Central Region of Ghana. Parasit Vectors. 2017;10:395.

31. Kusi KA, Bosomprah S, Kyei-Baafour E, Dickson EK, Tornyigah B, Angov E, et al. Seroprevalence of antibodies against Plasmodium falciparum sporozoite antigens as predictive disease transmission markers in an area of Ghana with seasonal malaria transmission. PLoS ONE. 2016;11:e0167175.

32. Kusi KA, Manu EA, Manful Gwira T, Kyei-Baafour E, Dickson EK, Amponsah JA, et al. Variations in the quality of malaria-specific antibodies with transmission intensity in a seasonal malaria transmission area of Northern Ghana. PLoS ONE. 2017;12:e0185303.

33. Partey FD, Castberg FC, Sarbah EW, Silk SE, Awandare GA, Draper SJ, et al. Kinetics of antibody responses to PfRH5-complex antigens in Ghanaian children with Plasmodium falciparum malaria. PLOS ONE. 2018;13:e0198371.

34. Lamptey H, Ofori MF, Kusi KA, Adu B, Owusu-Yeboa E, Kyei-Baafour E, et al. The prevalence of submicroscopic Plasmodium falciparum gametocyte carriage and multiplicity of infection in children, pregnant women and adults in a low malaria transmission area in Southern Ghana. Malar J. 2018:17:331.

35. Amoah LE, Abagna HB, Akyea-Mensah K, Lo AC, Kusi KA, Gyan BA. Characterization of anti-EBA175RIII-V in asymptomatic adults and children living in communities in the Greater Accra region of Ghana with varying malaria transmission intensities. BMC Immunol. 2018;19:34.

36. Afari EA, Appawu M, Dunyo S, Baffoe-Wilmot A, Nkrumah FK. Malaria infection, morbidity and transmission in two ecological zones Southern Ghana. Afr J Health Sci. 1995;2:312-5.

37. WHO. Microscopy for the detection, identification and quantification of malaria parasites on stained thick and thin blood films in research settings. Geneva: World Health Organization; 2015.

38. Amoah LE, Abagna HB, Ayanful-Torgby R, Blankson SO, Aryee NA. Diversity and immune responses against Plasmodium falciparum gametocytes in non-febrile school children living in Southern Ghana. Malar J. 2019;18:265

39. Ayanful-Torgby R, Oppong A, Abankwa J, Acquah F, Williamson KC, Amoah LE. Plasmodium falciparum genotype and gametocyte prevalence in children with uncomplicated malaria in coastal Ghana. Malar J. 2016;15:592.

40. Ayanful-Torgby R, Quashie NB, Boampong JN, Williamson KC, Amoah LE. Seasonal variations in Plasmodium falciparum parasite prevalence assessed by varying diagnostic tests in asymptomatic children in southern Ghana. PLoS ONE. 2018;13:e0199172.

41. Abagna HB, Acquah FK, Okonu R, Aryee NA, Theisen M, Amoah LE. Assessment of the quality and quantity of naturally induced antibody responses to EBA175RIII-V in Ghanaian children living in two communities with varying malaria transmission patterns. Malar J. 2018;17:14.

42. Okell LC, Bousema T, Griffin JT, Ouédraogo AL, Ghani AC, Drakeley CJ. Factors determining the occurrence of submicroscopic malaria infections and their relevance for control. Nat Commun. 2012;3:1237.

43. Kwenti TE, Kukwah TA, Kwenti TDB, Nyassa BR, Dilonga MH, EnowOrock $\mathrm{G}$, et al. Comparative analysis of $\lg \mathrm{G}$ and $\lg \mathrm{G}$ subclasses against Plasmodium falciparum MSP-1 19 in children from five contrasting bioecological zones of Cameroon. Malar J. 2019;18:16.

44. Vidarsson G, Dekkers G, Rispens T. IgG subclasses and allotypes: from structure to effector functions. Front Immunol. 2014;5:520.

45. Bousema JT, Roeffen W, van der Kolk M, de Vlas SJ, van de VegteBolmer M, Bangs MJ, et al. Rapid onset of transmission-reducing 
antibodies in Javanese migrants exposed to malaria in Papua, Indonesia. Am J Trop Med Hyg. 2006;74:425-31.

46. Morell A, Terry WD, Waldmann TA. Metabolic properties of IgG subclasses in man. J Clin Invest. 1970;49:673-80.

\section{Publisher's Note}

Springer Nature remains neutral with regard to jurisdictional claims in published maps and institutional affiliations.
Ready to submit your research? Choose BMC and benefit from:

- fast, convenient online submission

- thorough peer review by experienced researchers in your field

- rapid publication on acceptance

- support for research data, including large and complex data types

- gold Open Access which fosters wider collaboration and increased citations

- maximum visibility for your research: over $100 \mathrm{M}$ website views per year

At BMC, research is always in progress.

Learn more biomedcentral.com/submissions 